\title{
A COLLABORATIVE AUTO-ETHNOGRAPHIC EXPLORATION OF SOCIALLY JUST PRACTICES BY NEW ACADEMICS IN TWO SOUTH AFRICAN HIGHER EDUCATION INSTITUTIONS
}

\author{
K. S. Collett \\ Department of Educational Studies \\ University of the Western Cape \\ Cape Town, South Africa \\ e-mail:kcollett@uwc.ac.za \\ B. Von der Heyden* \\ Department of Geology \\ R. W. M. Pott ${ }^{*}$ \\ Department of Process Engineering

\section{J. Stander} \\ Division of Physiotherapy \\ *Stellenbosch University \\ Stellenbosch, South Africa
}

\section{ABSTRACT}

Challenges experienced in the higher education context require new academics to engage with issues of social justice in their pedagogical practices. This article focuses on such challenges and how these are met by the authors, who are new academics from two higher education institutions in South Africa. Using a collaborative auto-ethnographic approach to analyse and interpret practices from different disciplines and higher education institutions, critical insights into "response-able pedagogies" are highlighted. "Response-able pedagogies" may be described as those which foreground attentiveness, responsibility, curiosity and capability, are used as a lens to examine the pedagogical practices of the authors, as new academics. This lens is useful in that it illuminates ethical dimensions of how a socially just pedagogy might be enacted in disparate South African higher education contexts. Issues of language, academic literacies, resources, employability, cultural diversity, large classes, and student abilities are reflected upon in relation to new academics' engagement with socially just pedagogies. The article is intended to be a useful resource specifically, but not exclusively for, new academics entering the field of higher education in South Africa.

Keywords: collaborative auto-ethnography, Higher Education, new academics, political ethic of care, response-able pedagogy, social justice pedagogy 


\section{INTRODUCTION}

The expectations of a lecturer, both from the student body and from the higher education institution (HEI), have evolved significantly from the days of the archetypal "Ivory Tower" lecturer. To enable students to be functioning and contributing members of modern society, lecturers need to transcend didactic forms of course content transfer and engage with new enabling pedagogies. This article explores the experiences of four "new academics" (incumbent academics with less than two years of experience lecturing in Higher Education (HE)) in two differently positioned higher education institutions, as they navigated their way through the turbulent waters of the time of the \#FeesMustFall (FMF) and \#RhodesMustFall (RMF) student protests between 2015 and 2017. It illuminates how the curriculums and pedagogies employed by new lecturers can be shaped by an array of complexities currently present in the local HE environment. These include large class sizes, language diversity, diverse student cohorts (requiring variable student learning and support needs), and an increased drive towards utilising technology in modern teaching interventions.

While each of the authors explored different strategies and approaches to enhance student learning and improve our teaching, we all shared a commitment towards enhancing student agency in the learning processes. We all sought out opportunities to promote social justice and socially-just approaches, in which social change and activism occupy appropriately central themes (Breunig 2016). In this article we collectively explore, analyse, and reflect through a number of vignettes using the lenses of "Response-able pedagogy" (Bozalek and Zembylas 2017) and Tronto's Political Ethics of Care (Tronto 2013, 1993). We aim to highlight practice routes, ontologies and epistemologies which allow (new) academics to engage with, and enhance, the embodiment of justice, and appropriate learning opportunities for students. These perspectives help to illuminate the moral and political aspects of attentiveness, curiosity, responsibility and "rendering capable" in the teaching and learning (T\&L) process.

To guide the analysis, a collaborative auto-ethnographic approach, with selection of relevant "data which glow” using MacLure's (2013) conception of analysis, was used. This methodology is helpful in analysing practices from varying disciplines and HEIs, highlighting critical insights into response-able pedagogies - both where our practices have succeeded, and instances of failure or oversight. Issues of language, academic literacies, resources, employability, cultural diversity, large classes, and student abilities are reflected upon in relation the authors' engagement with socially just pedagogies. The article concludes by drawing out key insights and lessons which might help other new academics to navigate a path towards employing social justice and socially-just pedagogies in their curriculum design and delivery. It further highlights the strengths of a collaborative auto-ethnographic approach 
towards reflecting on and developing critical pedagogy as a community of practice, especially across multiple institutions and during a time of tumultuous socio-political climate.

\section{CONTEXT}

The HEIs in this study include Stellenbosch University (SUN), a historically white university (HWU), and the University of the Western Cape (UWC), a historically black university (HBU). Some of the differences in these HEI contexts are reflected in their student demographics, histories of engagement with the Apartheid state and disparities in infrastructure and resourcing. Wolpe $(1995,28)$ argued that the main difference among historically white and black HEI is "a de facto division, along racial lines, between "teaching" and "research" institutions, reflected in the relative strengths of HWUs and HBUs in the areas of graduate programmes and research." These differences continue to be played out in the current challenges these different HEIs face (Bozalek and Boughey 2012). For example, relative to the HWU, the HBU has in general larger classes, greater student diversity, is not as easily accessed, and has a lower funding base with a stronger teaching focus. Although these differences exist, new lecturers across both HEI's face similar challenges in providing quality learning opportunities for students, engaging with Information and Communication Technologies to enhance curriculum content, delivery and learning, and responding to diverse student learning and support needs.

At the advent of the authors' lecturing careers, the South African tertiary education space was dominated by the 2015/2016 Fallist movements. Fallism represents a broader manifestation of student disgruntlement with the status of the tertiary education system, and was strongly promulgated by the use of social media. The Fallist campaigns culminated in the nationwide \#FeesMustFall campaign calling for free and accessible HE, notably for the poor (Luescher 2016). At SUN, these campaigns focussed largely on the issues of language of tuition (e.g., \#AfrikaansMustFall, \#Luister, \#OpenStellenbosch), whereas at UWC the major protest included \#OutsourcingMustFall and \#FeesMustFall. For the new academic, these protests served to highlight the need for change, particularly through the design of socially just pedagogies and decolonising the curriculum. However, the protests also created a difficult space where engagement with the student body could be compromised by a binary "us versus them" tension (Müller 2017).

As new academics, we have needed to engage with these tensions and to do so we have had to understand and empathise with the injustices and struggles that the students we teach are faced with in our respective HEI contexts, where the medium of instruction is often a third language and knowledge forms and content are not always familiar. These issues highlight the need for new academics to underpin their pedagogy with critical, transformative and socially 
just teaching practices, and this thus forms the basis of our collaborative auto-ethnography.

\section{CONCEPTUAL FRAMEWORK}

In our analysis of our practice as new lecturers we draw on Bozalek and Zembylas' (2017) conceptualisation of a "Response-able pedagogy" to explore how we address social justice concerns in our pedagogy and course design. Bozalek and Zembylas (2017) assert that a "Response-able pedagogy" draws on and extends conventional notions of critical pedagogy as it is informed by a feminist neo-materialist ontology which foregrounds ethico-political practices:

"Response-able pedagogies are not simply examples of the type of learning that can take place when power, relations, materiality and entanglements are acknowledge; they also constitute ethico-political practices that incorporate a relational ontology into teaching and learning activities." (Bozalek and Zembylas 2017: 62).

They propose ethico-political practices of attentiveness, responsibility, curiosity and rendering each other capable as interrelated aspects of a response-able pedagogy.

Both a socially just and social justice approach are engaged with in exploring our practice. Moje (2007) gives a good definition of the first: she argues that a socially just pedagogy pays attention to aspects such as a focus on equitable opportunities to learn, equal access to learning resources and providing opportunities for all students to achieve social and economic success. Moje (2007) asserts that it has limitations, and may not be transformative as it does not take a critical stance towards engaging with the curriculum by deliberately challenging and questioning the content and pedagogy, nor does it engage students in actively participating in this process. It thus runs the risk of reproducing the status quo: the focus is on assimilation into dominant knowledge structures (Moje 2007).

Zembylas and Bozalek (2017) argue that socially just pedagogies have a role in that although they may "not eradicate structural inequalities, they can make a contribution to recognising and critically interrogating the issues that perpetuate these injustices ..." (Zembylas and Bozalek 2017, 1). They assert that "The notion of socially just pedagogies, then, has to consider specifically how it is entangled with notions of justice at the societal level and whether it really creates spaces in higher education that nurture relational values such as care, compassion, respect, and solidarity" (Zembylas and Bozalek 2017, 3). Furthermore they argue that a greater range of methodological and theoretical tools are required to "envision and enact socially just pedagogies in higher education" (Zembylas and Bozalek 2017, 3).

Bozalek and Zembylas (2017) "response-able pedagogy" holds resonance with Tronto's (2013; 
1993 ) political ethics of care, revealing how issues of social justice require an engagement with care ethics. We have chosen to explore our practices using the related aspects of how responseable pedagogy enabled student and lecturer agency within the context of our respective HEIs and conditions of the Fallist context in 2015 and 2016. Figure 1 provides a representation of the aspects of Response-able pedagogy.

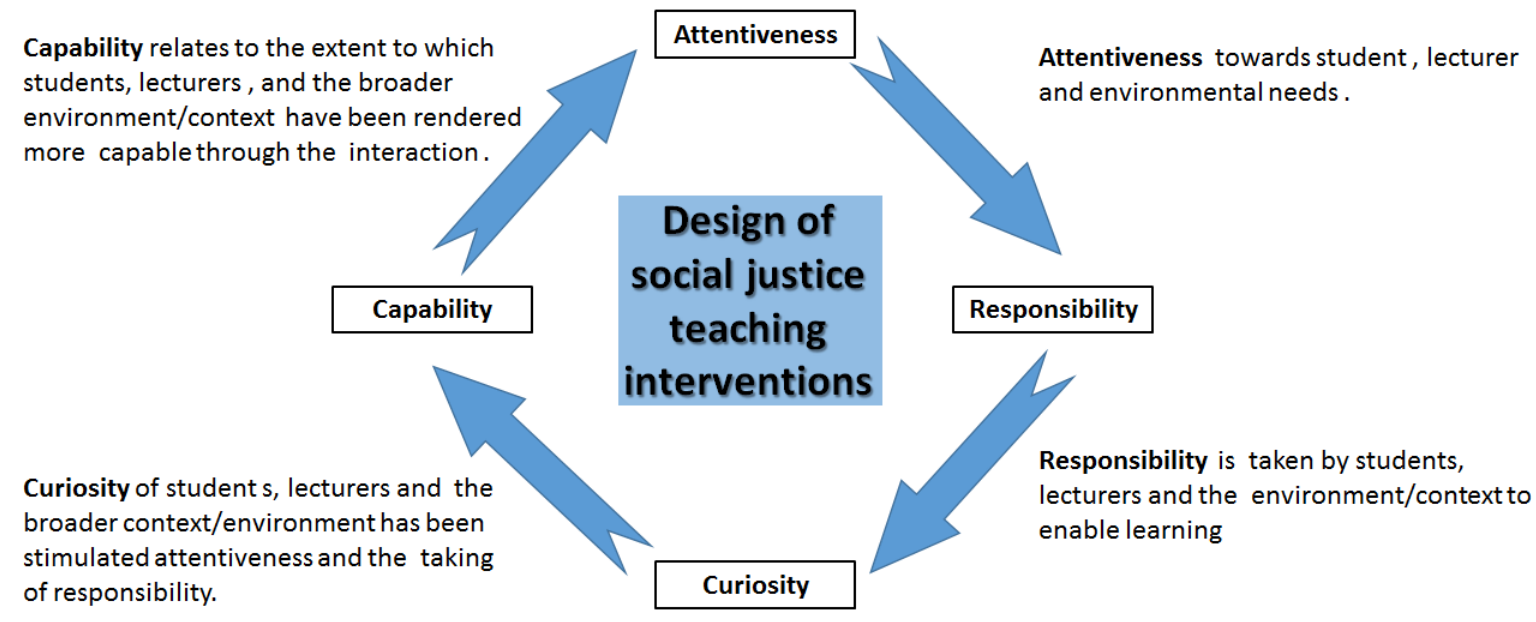

Figure 1: Design of social justice interventions using the Response-able Pedagogy framework (after Bozalek and Zembylas 2017)

\section{METHODOLOGY}

The first two years of an academics lecturing career represent a "teething period" in which the new academic must rapidly acquire a teaching skill set, whilst contending with the additional responsibilities of developing a research niche. The advent of a lecturing career during the 2015/2016 \#Fallism campaigns in South Africa's tertiary education sector added extra complexity to this. Our unique experiences of this time period thus form an interesting set of lenses through which to examine the process of becoming a lecturer at a time when social justice and socially-just pedagogies were being emphatically highlighted. We have selected autoethnography, a qualitative research methodology that utilises the self to examine sociocultural contexts and phenomena (Chang, Ngunjiri and Hernandez 2016; Reed-Danahay 1997) to engage with our teaching practices. Autoethnographic approaches have previously been utilised successfully, for example, to interrogate the becoming of a University scholar (Hernández et al. 2010); and to interrogate the professionalization of teaching practice (Canagarajah 2012). Although we identify with these works, our placement at the advent of our career translates to us individually having a relatively lesser degree of experience in evaluating 
our teaching and learning practices. We therefore decided on a collaborative autoethnographic approach in which each individual's reflection could also benefit from cooperative analyses and engagement by similarly placed peers. The benefits of collaborative autoethnography are well documented (e.g., Short, Turner, and Grant 2013; Chang et al. 2016). We will expound on its value to the reflecting new academic in our discussion below.

Table 1 summarises the exact methodology that we employed in collaboratively and autoethnographically evaluating our teaching practice in the ambient South African higher education climate. Our approach combines elements of solo and collective reflection on our teaching interventions and their value towards attaining a socially just learning environment. Our approach is iterative and the meaning-making occurs over a year long time period. This protracted period of interaction was highly beneficial to us, since the collaborative approach also served to guide our growth towards becoming more critical and socially-aware. The collaboration benefitted from unique perspectives from "new" academics from different HEI's and from different research fields. The collaboration also benefited from utilisation of ICT's such as Skype and Google Docs, although human interaction factor was retained through regular and interspersed face-to-face meetings ( $\sim 35 \%$ of total collaborative interaction).

For the ethnographic report writing phase (Phase 9; Table 1), we concentrated on "data that glows" (MacLure 2013) to highlight instances in which our respective interventions epitomised the principle components of the Response-able pedagogy (Figure 1). Subsequent detailed and collaborative evaluation of our interventions has enabled us to critically discuss the necessity for academics to include social justice considerations in their curricula content and in developing and refining their pedagogies. We further evaluate our journey as collaborative auto-ethnographers to comment critically on the affordances of this approach towards growing as more mature and socially aware scholars of T\&L.

Table 1: The work-flow phases of the collaborative auto-ethnographic methodology

\begin{tabular}{|c|c|c|c|}
\hline Stage & Activity & Players & Phase $^{1}$ \\
\hline 0 & $\begin{array}{l}\text { "New" academics conceptualise, design, run, and } \\
\text { superficially evaluate novel teaching interventions }\end{array}$ & Solo & \\
\hline 1 & $\begin{array}{l}\text { Presentation of teaching practice at a regional inter- } \\
\text { university New Academics Research Colloquium } \\
\text { (NARC) }\end{array}$ & Solo & \\
\hline 2 & Individual reflection on teaching practice & Solo & Data collection \\
\hline 3 & $\begin{array}{l}\text { Analysis of individual reflection pieces, commonality } \\
\text { (a focus on students) identified and the small group } \\
\text { collaboration initiated }\end{array}$ & $\begin{array}{l}\text { Collective } \\
\text { (large group) }\end{array}$ & Data analysis \\
\hline 4 & $\begin{array}{l}\text { Extended reflection on teaching practice in a } \\
\text { context of the broad topic of "a focus on students' }\end{array}$ & Solo & Data collection \\
\hline 5 & Critical analysis of self and peer reflective pieces & Solo & Data analysis \\
\hline 6 & $\begin{array}{l}\text { Discussion on individual analyses, refinement of the } \\
\text { common theme (social justice the lens of }\end{array}$ & $\begin{array}{l}\text { Collective } \\
\text { (author group) }\end{array}$ & Data analysis \\
\hline
\end{tabular}




\begin{tabular}{|l|l|l|l|}
\hline Stage & Activity & Players & Phase $^{1}$ \\
\hline 7 & Response-able pedagogy) & & \\
\hline 8 & $\begin{array}{l}\text { Self evaluation and self writing of teaching practice } \\
\text { through identified lens and in a context of the } \\
\text { identified theme }\end{array}$ & Solo & $\begin{array}{l}\text { Data analysis and } \\
\text { subsequent data } \\
\text { collection }\end{array}$ \\
\hline 9 & $\begin{array}{l}\text { Evaluation of peers' interpretation of their teaching } \\
\text { practices using social justice as a back-drop }\end{array}$ & $\begin{array}{l}\text { Collective } \\
\text { (author group) }\end{array}$ & $\begin{array}{l}\text { Data analysis and } \\
\text { interpretation }\end{array}$ \\
\hline $\begin{array}{l}\text { Conclusions drawn related to the social justness of } \\
\text { our teaching, and on the power of collaborative } \\
\text { auto-ethnography to improve lecturer capabilities }\end{array}$ & $\begin{array}{l}\text { Collective } \\
\text { (author group) }\end{array}$ & Report writing \\
\hline
\end{tabular}

${ }^{1}$ Phases after Chang et al. 2016.

\section{PRESENTATION AND ENGAGEMENT WITH PRACTICE}

In response to contextual complexities, we engaged in a range of practices informed by relevant T\&L theory. These practices and the beliefs, intuitions, and theories that informed them are engaged within our individual and collaborative analysis. This section will present the interventions and programs initiated by each author, and then examine each with respect to the lenses of "Response-able Pedagogy" (Bozalek and Zembylas 2017). From this we then draw key insights into how this is underpinned by a desire to design socially just T\&L practices.

The four academics used different $\mathrm{T} \& \mathrm{~L}$ frameworks in designing their individual interventions. Here we briefly introduce the four interventions (Table 2), after which we evaluate them using the lens of "Response-able Pedagogy".

RP, and his colleagues co-teaching the module, applied Legitimation Code Theory (LCT), which allowed insight into the route of knowledge development through the plotting of learner experience on the semantic and epistemic planes (Maton 2013, 2009; Pott, Wolff, and Goosen 2017). JS embedded a "flipped classroom" approach into a curriculum designed using the "Learning Designer" online tool, aligning the case's learning activities and assessment, ensuring time allocation was reflective of a learning objective with active student engagement (Bower et al. 2011). Similarly, Laurillard's "ways of learning" (Laurillard et al. 2013) underpinned the telephonic interview initiative designed by BvdH. Finally, author 1 focused on improving online and face-to-face opportunities for peer formative feedback, authentic learning (Herrington and Oliver 2000) and constructive alignment (Biggs 1999).

Table 2: Key interventions and theoretical underpinnings

\begin{tabular}{|l|l|l|l|}
\hline Intervention & Description & Theoretical underpinning & Convenor \\
\hline $\begin{array}{l}\text { Technology- } \\
\text { assisted peer } \\
\text { feedback on } \\
\text { assignments }\end{array}$ & $\begin{array}{l}\text { Use of Turnitln software to support peer } \\
\text { and marker formative feedback on } \\
\text { written assignments }\end{array}$ & $\begin{array}{l}\text { Design-based Research } \\
\text { Constructive Alignment (Biggs } \\
1999 ; \text { Herrington and Oliver } \\
2000)\end{array}$ & Author 1 \\
\hline $\begin{array}{l}\text { Online quiz to } \\
\text { enhance threshold } \\
\text { concepts }\end{array}$ & $\begin{array}{l}\text { Enhance i) unit conversion and ii) } \\
\text { quantity estimation proficiencies in large } \\
\text { classes using repeated online quizzes }\end{array}$ & $\begin{array}{l}\text { Legitimation Code Theory } \\
\text { (Maton 2013) }\end{array}$ & $\begin{array}{l}\text { Author 3 } \\
\text { and } \\
\text { colleagues }\end{array}$ \\
\hline
\end{tabular}




\begin{tabular}{|l|l|l|l|}
\hline Intervention & Description & Theoretical underpinning & Convenor \\
\hline $\begin{array}{l}\text { Podcasts and } \\
\text { quizzes for } \\
\text { revision of } \\
\text { threshold concepts }\end{array}$ & $\begin{array}{l}\text { Student preparedness during practicals } \\
\text { enhanced by prior engagement with } \\
\text { online learning material }\end{array}$ & $\begin{array}{l}\text { Flipped classroom } \\
\text { (Bower et al. 2011) }\end{array}$ & Author 4 \\
\hline $\begin{array}{l}\text { Telephonic } \\
\text { interviews with } \\
\text { industry specialists }\end{array}$ & $\begin{array}{l}\text { Students required to investigate the role } \\
\text { of the geologist in the mining industry } \\
\text { and to understand the importance of } \\
\text { professional networking }\end{array}$ & $\begin{array}{l}\text { Laurillard's Conversational } \\
\text { Framework } \\
\text { (Laurillard et al. 2013) }\end{array}$ & Author 2 \\
\hline
\end{tabular}

\section{Attentiveness}

Multiple authors have considered the importance of attentiveness (Bozalek and Zembylas 2017; Taguchi 2012; Barad 2007). Within the framework of response-able pedagogy, "Attentiveness" occupies a central theme and has been defined as "the ability to apprehend, to listen, to be open and respectful, and the ability to inhabit just practices in a collective space" (Bozalek and Zembylas 2017). As teaching academics, our classrooms and online learning platforms are the collective spaces in which we interact with our students, and our attentiveness towards their needs is best represented by the student-centered approaches that underpin our respective teaching interventions. In addition to being cognisant of student needs, our interventions and the subsequent collaborative diffraction thereof, highlighted the importance of being attentive to our own needs as lecturers, as well as being attentive to the socio-political and material environments in which we (as students and lecturers) co-exist.

Author 1's intervention sought to directly enhance the retention and achievement through strengthening on-line and face-to-face mechanisms for peer and marker feedback on formative assessment tasks. This intervention paid attention to the need for increased levels of student support in a HEI context where students were not writing and learning in their first (or sometimes second) language. In the design of her curriculum she had to pay attention to scaffolding peer and marker attentiveness towards a set of common agreed upon criteria for improved writing and referencing. Attentiveness to the type of feedback students provided to each other and how student felt about the feedback they received helped to highlight the importance of strengthening face-to-face processes to enhance class cohesion and trust. The affordances of TurnItIn technology enabled greater opportunities for attentiveness in providing individualised and timely formative feedback in large classes. The technology as well as design of assessment activities provided increased opportunities for students to pay attention to their own writing towards a final summative task. The processes assisted students to more adequately prepare for examinations throughout the periods when student were not able to access campus.

Using on-line technology to enhance formative assessment enabled her to pay attention to 
her own needs for systems of support to develop academic literacies, as well as reduced marking fatigue. She noted, "as a lecturer I needed to find strategies that would help me cope with the physical demands of supporting academic writing and marking in large classes, a well and the challenges of a context where a range of alternative and flexible forms of assessment were required to support students and keep the academic programme on track." Although online connectivity enabled deepened learning for those student who had access to technology and the internet off-campus, it did not enable the lecturer or peers to pay attention to the support needs of those students who could not afford to privately fund these resources during the Fallist movements.

Author 3 enhanced student attentiveness through facilitating an opportunity to repeatedly attempt, recognise error, and try again - and through the process develop and practice skills. These multiple opportunities allowed for both the students themselves, as well as the lecturers, to enhance attentiveness to the students' needs for development (and achieved development through the process). This attentiveness to student development of expertise is often difficult to mediate in large classes.

Through the analysis of previous years' experience, lecturers saw that in the case of these skills it was key to be attentive to the difficulty many students experience in developing, or even knowing how to develop the skills, clearly illustrated by each student's competency trajectory through the multiple tests. The intervention allowed for a focusing of their minds, without overburdening the lecturers with large marking or explanatory loads. Through the use of the ICT platform, RP and colleagues could note where students continued to battle, and respond appropriately in class. However, the use of ICT can work to dehumanise, or separate students from interactive learning, and so while the intervention was aimed at improving student success through online testing, the convenors were cognisant of the continued requirement for interpersonal T\&L as well.

Graduate employment prospects during the 2011-2016 period were significantly decreased because of low global metal prices. Author 2's attentiveness to these broader macroeconomics impacts, and his inherent concern for his graduating students' employability, led to the development of his telephonic interview intervention (Von der Heyden 2018). The interviews were designed to enable the entire student cohort (irrespective of background) to engage with active learning about the demands of the Southern African minerals industry, thereby enabling them to be better prepared for post-university life. Through interacting with professional Geologists, students attained a much greater understanding of the expectations demanded by a professional career, and developed a much keener awareness of the pertinence and applicability of their University training. Through running the intervention and gauging the 
students' responses, author 2 realised the importance of providing students with a platform to interact with industry partners. Upon reflection on the intervention, he has realised that the learning opportunity could be enhanced if amicable industry partners are pre-arranged and given the charge of providing mentorship, critical and insightful advice to the student caller. Nonetheless student feedback on the intervention indicated that they benefited from a growth in confidence with respect to their job search prospects.

Author 4 focussed on attending to the student's lack of mastery of threshold concepts, using a flipped classroom to engage them in various modes of epistemic access. Neve, Wearn, and Collett (2016) and Land, Meyer, and Flanagan (2016) emphasised the importance of students mastering threshold concepts, ensuring their understanding and application of knowledge in clinical settings. She employed a "flipped classroom" approach and gave the students a structured format to base their preparation of the practical session on. She wanted to listen to the needs of both the facilitator and the student, to optimise the learning experience and improve the student's ability to achieve mastery of threshold concepts.

Students' ability to complete assignments or prepare for class activities need to be closely assessed to ensure that the students are equipped to perform these tasks, both in their preparedness to access and use the new formats and environmental factors. The availability of time, cellular data and skills to perform novel ways of preparing and attending learning activities were all considered when autor 4 planned to implement the approach. This was particularly important during the \#Fallism time period, during which the atmosphere on University campus was compromised by protest action. Author 4 was attentive in determining ways that the students would be able to access the planned activities. The podcast and quiz activities were built into the available contact time to ensure that it was not expected of the students to invest time that was not available to them. The students felt that they did benefit from these activities, with one commenting: "It showed me where I stand in terms of my current knowledge”.

\section{Responsibility}

Here we break from the convention of Bozalek and Zembylas (2017) by choosing to discuss the element of responsibility before the element of curiosity in reflecting on our teaching practice. We believe that whereas our teaching interventions originate from our innate attentiveness to student needs, the designs of the interventions are more strongly influenced by our desire to place a greater proportion of responsibility for learning in the student domain. We also recognised our key role in designing the learning environment to promote agency. That is, we believe that for effective learning to take place, it is imperative that students take a share of 
the responsibility for their learning. This sharing acknowledges the inherent nature of responsibility which is that it is a property of multi-directional, often-asymmetrical relationships (Barad 2007; Bozalek and Zembylas 2017). We engage with how we take responsibility for the students learning, in our the design of the interventions or how we engage students in taking responsibility for and generating knowledge and taking greater agentic responsibility for their own learning and the learning needs to their peers. And also engage with how the conditions within the material and social environment enable both student and lecturers to take on responsibility.

Learning cannot be placed purely in the student domain, as this would run risks of being ineffectual due to lack of direction and similarly cannot be placed purely in the lecturers' domain, as this would render it an instructive based learning practice which is somewhat archaic and not well suited to the modern student cohort. Thus an effective learning intervention includes elements of student centeredness, but the roles and responsibilities of the lecturer must also be clearly defined and considered in a context of the aptitude and background of the student cohort.

Author 1 took responsibility to enhance systems of student peer and marker formative feedback towards the development of their academic writing and thinking. Her curriculum design focused on an inclusive approach to the development of academic literacies. By making assessment criteria and rating transparent to students she responded to the needs of students to know what criteria they are assessed on and scaffolded their ability to give feedback comments to peers.

The used of TII technology as well as the design of assessment tasks required students to take responsibility to meet their own needs for obtaining feedback by posting a task on-line in order to receive feedback. The technology enabled the lecturer to respond more ably to increased levels of formative feedback to students, as well as take responsibility for reducing the stress of writing out feedback comments. However using technology to support learning and feedback also raised concerns about social justice issues in relation to how students could gain access to learning if they did not have access to a computer or the internet. This was the lived reality of many student when campuses were closed at the height of the \#FMF movement.

The online unit conversions and estimation test that RP and colleagues instituted arose in response to the fact that in previous years students did not take responsibility for their own learning of these skills. The aim was to allow the students space to realise that the development of these skills is not trivial or instantaneous; indeed, as one student commented "I found the test challenging but not impossible. It definitely made me realize that I need some more practice at converting units". 
The intervention was therefore aimed at repositioning the responsibility for facilitating the learning with the lecturer, and the action of learning with the student. The balance between learner-lecturer responsibility is a tension which shifts away from lecturer towards student, as the student progresses through their degree. RP acknowledges that students cannot be expected to operate as fully responsible professionals (as engineers in this case) from their first day, but should rather be increasingly burdened with responsibility, and scaffolded to accept it over time. This intervention therefore relieved some responsibility-burden from the students, placing it with the lecturers. A key difficulty in such large classes is managing to help students from varying backgrounds (and therefore differing "responsibility adverseness") to accept the required responsibility. The multiplicity and limited consequences for failure in these online tests help more responsibility-averse students to shoulder the burden of their own skills development.

Author 2 (who had two years of professional industry experience) identified and took responsibility for his limitations related to his knowledge of the role of the geologist in the minerals sector. He thus selected to use more experienced industry partners as a resource to promote student learning (i.e., through interview interactions). He designed the extended intervention using Laurillard's (2013) Conversational Framework, which ensured that affective learning could take place using a number of different modes of learning (e.g, Acquisition, Inquiry, Discussion, Production). For students to achieve maximum value from the interview part of the intervention, he further took responsibility for training students to conduct interviews in a professional, respectful and competent manner, thereby enhancing their graduate attributes.

Students, in return, took a share in the responsibility for the success of the intervention by structuring their interviews such that they would attain the greatest learning interaction. By stepping up to this responsibility, students became knowledge producers and were able to take ownership for their own learning, by guiding the interview in directions that were most beneficial towards augmenting their existing knowledge of the subject matter. This approach inherently led to a "decolonisation" of the curriculum, resonating well with the calls and student sentiments of the \#Fallism movement. This ownership allowed the student cohort to construct their highly individualised knowledges at their own pace and in their own manner, thereby negating the deleterious consequences of trying to teach all students in the same way.

The flipped classroom approach that author 4 used shifts focus away from didactic teaching, to the students' taking responsibility to prepare and revise their knowledge-base to ensure that threshold concepts are well laid down. The students taking responsibility for their own learning changes the role of the academic from the "imparter of knowledge" to the facilitator. The students were also responsible for peer-to-peer learning activities during contact 
time. This relates to the student not only being responsible for their own learning, but also the learning experience of their fellows.

\section{Curiosity}

Under the aspect of curiosity we explore the effectiveness of our interventions, and the importance of engaging with response-able and socially just pedagogical practice. Questions we grappled with are, "Have our interventions managed to enhance curiosity about the subject matter?" "How effective were our interventions in regard to engagement with subject matter or broaden the knowledge base and discourse engaged with?" "How have our design of learning processes enhanced student curiosity or raised further questions about our own practice?"

Curiosity has been identified as an important aspect in the T\&L environment (Bozalek and Zembylas 2017), particularly when it is used to create surprising and unanticipated encounters either with the course content, or on an interpersonal level. As Kang et al. (2009, 963) put it, "curiosity is the wick in the candle of learning", that is, with curiosity comes perseverance and, in the end, knowledge and skill development.

Author 1: Formative feedback is more strongly geared towards enhancing student curiosity about their own writing and thinking than summative feedback where opportunities for students to improve on their writing and thinking are limited. Feedback comments helped students to think about further sources, as well as how they could change their writing structuring. The design of formative assessment tasks promoted enhanced opportunities for students to find out more about how they could improve their writing and thinking through sharing and reading the work of other students. Having to provide feedback to peers required student to internalise criteria for good academic writing as a well as deepen their engagement with the knowledge content. This enhanced their curiosity to engage with assessment criteria. Reading student feedback comments helped to raise the curiosity by her about aspects of academic literacy she needed to scaffold into the design of her teaching.

Of the skills the students develop through author 3's online test, students find estimations the most foreign and difficult. The use of the "Fermi estimates" methodology (one skill we teach and assess in this intervention) to arrive at a "rough" estimate of a problem first confounds and exasperates, and finally stimulates and develops the students' wonder. For instance, one student commented:

\footnotetext{
"The estimations were challenging but very fun as it caused me to consider things which I have never thought of before."
} 
The paradigm shift away from a "doctrinal" (using Maton's terminology) view of "plug-andplay" problem solving to "situational" one, requiring unpacking, estimating, and evaluating is a difficult shift for students to make but one which is essential to their being good engineers. This intellectual curiosity, which gives rise to a problem solving mentality, is perhaps one of the key characteristics engineering educators strive to induce in their students (as discussed in Haase et al. (2013)).

Author 2 regards true scientific fascination as the single most important outcome of the B.Sc. degree program. His sentiments echo with those of Charles Darwin, who, in his recorded correspondence (1847-50), states:

"I believe there exists, and I feel within me, an instinct for the truth, or knowledge or discovery, of something of the same nature as the instinct of virtue, and that our having such an instinct is reason enough for scientific researches without any practical results ever ensuing from them."

The telephonic interviews inherently required students to be enquiring and curious about the role of the Geologist in the minerals industry. Their lines of questioning enabled them to discover truths and knowledge related to the daily responsibilities of the professional Geologist and related to the nuances of post-graduate employment. Students selected to engage with a variety of themes during their interviews, and questioning lines focussed on technical issues related to the mine-specific Geology, the economics of the mining operation, social and environmental awareness, and personal and interpersonal interaction. The interpersonal nature of some of the questioning lead to the development of relationships between the student and the interviewee, and through this experience, students learned about the value of professional networking. This networking opportunity further enabled Industry curiosity of the University and education environment, thereby bridging the gap that exists at the University-Industry interface.

Author 4 stimulated the curiosity of students by giving them structured, out-of-class activities to assist them with preparing for contact sessions. They found it to be a more interactive way of engaging with the content. They were able to function as independent learners within clear parameters of applying different forms of learning, including inquiry and discussion, as addressed by Laurillard et al. (2013). In this way, the flipped classroom assisted the students to transcend from acquisition of knowledge (which happened through their previous two years of study), to its application through new ways of thinking.

\section{Capability}

Being rendered capable has previously been related to "enlarging the competency of all players" 
and "enabling the capacity to respond to what matters" (Bozalek and Zembylas 2017, 69). We regard the process of being rendered capable through a teaching intervention as an ultimate manifestation of the previous three steps (viz., attentiveness, responsibility, and curiosity (Figure 1)). We reflect on how through the process of our learning we have become more capable as lecturers and scholars of T\&L. Similarly, we focus specifically on how our interventions and pedagogical approaches have rendered our students more capable as future leaders in their professions and society at large.

Author 1's intervention modelled promising practices to render students capable in providing online formative feedback towards a summative assessment task. As student teachers this experience served to raise their awareness of the importance of peer and technology assisted formative feedback thus providing positive role modeling for their future careers.

Rendering students capable included finding out what feedback on academic writing students found most useful and engaging students with the criteria against which they would be assessed. Rendering capable also included a focus on building student understanding and ownership of the value of peer feedback in their own learning and assessment. Providing multiple opportunities for feedback and reworking of writing and thinking gave students more opportunities for improving their task before a final submission. Students comments on other student tasks showed how criteria for the assessment task related to writing, referencing and content were being applied.

For author 3's, this was realised through the unit conversions and estimation test reenforces "capability" in the students, through a repeated attempt methodology. The test emphasises, and allows the students to practice, taking a core skill (which often boils down to simple algebra) and applying it to various and changeable situations and applications. In order to succeed the students need to take a "doctrinal" methodology (one where they see the "shape" of a problem, and simply repeat the mathematics as they have seen before), abstract the meaning of the method, and apply it to other, previously unseen types of problems. This transversal of the epistemic plane leads to capable students, by which we mean, students who undergo this shift are then capable of tackling more generalised, more situational, calculations and problems. Through this process the student gains agency in seeing failure developing to later success, as they are "rendered capable" (through their own actions), facilitated by the intervention.

The outcome of our intervention seemed to show that students were indeed rendered more capable (at performing calculations using these skills, and more generally, becoming problem solvers, and therefore better engineers). As discussed above, in the section on attentiveness, it may be that through channeling the students' attentiveness on these skill sets, we bring about the development of their capability. 
Author 2's interview intervention enabled students to attain a better understanding of the demands and expectations of a post-university career. Furthermore, the learnings and experiences that students achieved through this intervention are expected to contribute towards both the students' job search self-efficacies and particularly, to their job search clarities (e.g., Wanberg, Hough and Song 2002; Zikic and Saks 2009) The interview experience has also enabled students to develop within a social dimension (i.e., the affective domain (Anderson et al. 2001)) though professional one-on-one interactions with industry-based Geologists. This marks the first steps towards students developing their own professional networks, which can later be used when searching and applying for post-university employment. The interview has thus rendered students more capable and more competitive for entering into the job market by increasing their and their knowledge of, and levels of preparedness for the South African minerals industry. Students further benefited from the opportunity to develop social capital and professional networks, and this opportunity was exceedingly important particularly with poorer and less-connected students in the cohort.

By developing the unique learning intervention, and subsequently reflecting critically thereupon, Author 2 has enhanced his capabilities as a lecturer. He has come to understand the importance of designing $\mathrm{T} \& \mathrm{~L}$ interventions that enable students to actively construct knowledge and he now understands that these interventions are best designed using an informed and apt theoretical T\&L framework. From the student feedback, from engaging in pertinent T\&L literature, and from collaborating with his co-authors, he has further come to realise that socially-just learning interventions should seek not only to enhance student capabilities in the cognitive domain, but should also enhance their affective learning (in alignment with e.g., an institution's desired graduate attributes). These levels of reflective understanding will enable the early career lecturer to improve as he develops his career.

Author 4: Students struggle to bridge the divide between theory and practice, especially progressing from the acquisition of threshold concepts to applying these concepts when treating patients in clinical settings. The flipped classroom employed podcasts and quizzes to help the student prepare for contact time in which they have to plan the most appropriate treatment of a fictitious patient. This is a crucial step in developing critical thinking skills that the student will use in the management of patients when they are placed on a clinical platform. This rendering capable translates directly to improved clinical practice and improved clinical reasoning skills. The flipped classroom also addresses the need for revision of previously acquired knowledge or threshold concepts. This assists the "struggling student" to revise concepts and improve thinking skills at their own pace and lessens the anxiety of not being able to progress through the stages of learning. 


\section{DISCUSSION}

The preceding discussions have focussed on the interventions and practices the authors implemented, and their examination, reflection, and refraction on these practices through the lense of a socially just and response-able pedagogy. Through highlighting practice routes, ontologies and epistemologies which allow (new) academics to engage with, and enhance, the embodiment of justice, and appropriate learning opportunities for our students we hoped to illuminate socially just pedagogies, encapsulated in the moral and political aspects of i) attentiveness, ii) curiosity, iii) responsibility and iv) capability in the T\&L process. This section will attempt to, firstly, draw down some key insights and lessons which might be of interest to new academics as they navigate a path towards a social justice pedagogy in their curriculum design and delivery. Secondly a discussion of the collaborative auto-ethnographic methodology, and its use in refracting through our practices will be outlined.

\section{Socially just learning promoted by response-able pedagogy interventions}

The authors all approached their teaching with a desire to improve their practice, to more responsibly assist our students - a care for their development, an attentiveness to their needs (which both includes intellectual needs as well as broader psycho-social and contextual needs). Each of us approached the respective issues we identified with an intuition towards what forms of intervention would best "bridge the gap", identified in each class.

The differing institutions in which we operate significantly dictate the possible routes and methods available to us (and our students. For instance, some students have limited internet access). Further, with \#FMF even affordances usually available were potentially compromised. In this atmosphere our implementations were constrained, but still aimed towards the Responseable.

The lecturer's role in the implementation of classroom interventions is a balance between their own responsibility for the learning (and care) of the students, as well as the developing responsibility of the students for their own learning and care of peers. The lecturer must be cognisant not to tip the balance too far in either direction at the wrong point (Bozalek and Zembylas 2017). Here there is some dissonance with Tronto's model, which defines responsibility only in the domain of the carer (i.e., once the need has been identified, you have to take responsibility for righting that need).

We believe that the effective lecturer has a dual role of 1) creating learning interventions that encourage students to become curious about their learning material, and 2) being available to the students as a role model as one who is him/herself intimately curious about the world in 
which we live. Students, on the other hand, should actively endeavor to cultivate their own sense of curiosity, such that on completion of their tertiary education, they will enter into the world as truly curious and truly fascinated individuals.

The final goal outcome of HE is to have enabled students to become players in the larger community - to be capable of performing as agents in their respective fields. To effectively be this they need to both have the knowledge and skills, as well as being social actors - and so the development of a response-able pedagogy within the lecturing environment is entirely appropriate, since it seeks to develop and underpin that aspect of students' capability.

All of this is to say that, through the new lecturers' intuitions here, developed approaches, interventions, and pedagogies which exhibit various aspects of a response-able framework. A response-able pedagogy allowed for unpacking and examining which aspects do subscribe or support a socially just learning experience, and, more importantly, highlight where interventions can fail in their ethics of care. The mechanism of investigation - the collaborative autoethnographic methodology - allowed for this unpacking.

\section{Collaborative autoethnography strongly promotes new academics' lecturing capabilities}

Although reflection on one's teaching practice should be, and for many is, a continuous process, we have found that the two year milestone marks a highly relevant time point for the "new" academic to reflect critically on his or her pedagogical attitude and approaches. Importantly, this two year time frame allows sufficient time for the individual's course development and refinement; and having taught two iterations of a course enhances one's confidence and will have provided opportunity for interaction for two separate and different groups of students. Related to our designed teaching interventions, our individual reflections at this time point (Table 1; Phase 2) comprised questions such as:

"Has my teaching intervention been effective?"

"Did I solicit the sought after responses and learning outcomes from my students?"

Such lines of questioning, although directly related to teaching practice, reflect a degree of superficially that may perhaps be expected from the "new" and relatively inexperienced academic. It was only through our collaborative interactions during phases 3 to 6 (Table 1), that our reflections became more critical with respect to the impacts of our interventions on issues of social justice. To this end, the use of the "Responsible Pedagogy" framework was most useful towards our engagement with the scholarship of T\&L (Section 6.1). Our questions during these 
phases of our journey matured to consider the social justice value of interventions, and also moved away from the student centeredness to rather focus on the lecturer-students-other relational ontology of the learning environment:

"Has my teaching intervention been effective for my current student cohort, and has it taken full cognisance of the ambient socio-political atmosphere in which we exist?"

"How have my students, and how have I, grown through this intervention towards achieving the ends of a more socially just society?"

Further analysis of our second phase of reflections, particularly within our collaborative environment, enabled us to transcend the intervention-scale reflection on our teaching practice. This aligns somewhat with the sentiments of Warren (2011), who notes that it is important to move from a paradigm of "what I believe about teaching" to "why I believe what I believe about teaching". The collaborative approach was particularly useful towards this end (Table 1; Phase 8), since our evaluations necessarily extended beyond our own intervention to that of our peers; and we were each able to benefit from the objective insights of our peers and from group meaning-making (e.g. Chang et al. 2016).

This peer interaction offered critical, varied, and meaningful evaluation of our practice; since our collaboration comprised individuals from different HEI's and different academic fields, but who were undergoing similar experiences during the 2015-2016 \#Fallism movements. However, we do acknowledge that that the collaborators were all from one relatively-privileged socio-cultural class, and that the effectiveness of our collaborative autoethnographic approach would greatly benefit from a wider contestation with more sociocultural diversity. We look forward to further professional and personal growth in which our approaches and reflections will consider, for example:

"How do my teaching interventions and my pedagogical approach and practices align with sustainably and dynamically achieving a more socially just society?"

"In my curriculum design, am I attentive to my own and my students' needs; is there sufficient responsibility-sharing for student learning; am I inspiring curiosity in and rendering capability to both myself and my students?"

We hope that our collaborative meta-analysis of our teaching practice, documented here as an auto-ethnographic journey, can serve as an inspiration and as a model for other "new" academics who have set out to make a success of their careers whilst simultaneously contributing meaningfully towards the development of a more socially-just and socially-aware society. 


\section{CONCLUSIONS}

Four new academics presented, discussed, reflected on, and refracted through the T\&L implementations they had put in place in their disparate courses and institutions, through the lens of a socially just pedagogy. A collaborative auto-ethnographic approach enabled a richer and more nuanced understanding of where their practices supported a socially just pedagogy, and, perhaps more importantly, where aspects were lacking.

This lens is useful in that it illuminates ethical dimensions of how a socially just pedagogy might be enacted in disparate South African higher education contexts. Issues of language, academic literacies, resources, employability, cultural diversity, large classes, student abilities are reflected upon in relation to new academics' engagement with socially just pedagogies. The article is intended to be a useful resource specifically but not exclusively for new academics entering the field of higher education in South Africa.

\section{ACKNOWLEDGEMENTS}

The authors wish to thank the New Academics Regional Colloquium team from the Western Cape for the initial spur to this work. Thanks to Prof. Vivienne Bozalek for her invaluable help and guidance. Author 3 would like to acknowledge his engineering chemistry colleagues, who all collaborated on the intervention discussed here.

\section{Disclosure Statement}

No potential conflict of interest was reported by the authors.

\section{REFERENCES}

Anderson, Lorin, David Krathwohl, Peter Airasian, Kathleen Cruikshank, Richard Mayer, Paul Pintrich, James Raths and Merlin Wittrock. 2001. Taxonomy for learning, teaching, and assessing, A: A revision of Bloom's Taxonomy of Educational Objectives. White Plains, New York: Longman.

Barad, Karen. 2007. Meeting the universe halfway. Duke University Press.

Biggs, John. 1999. What the student does: Teaching for enhanced learning. Higher Education Research \& Development 18(1): 57-75.

Bower, Matt, Brock Craft, Diana Laurillard and Liz Masterman. 2011. Using the learning designer to develop a conceptual framework for linking learning design tools and systems. In International LAMS and Learning Design Conference, 61-71.

Bozalek, Vivienne and Chrissie Boughey. 2012. (Mis)Framing higher education in South Africa. Social Policy \& Administration 46(6): 688-703.

Bozalek, Vivienne and Michalenos Zembylas. 2017. Towards a response-able pedagogy across higher education institutions in post-apartheid South Africa: An ethico-political analysis. Education as Change 21(2): 62-85. 
Breunig, Mary. 2016. Critical and social justice pedagogies in practice. In Encyclopedia of Educational Philosophy and Theory, ed. Michael Peters. Singapore: Springer.

Canagarajah, A. Suresh. 2012. Teacher development in a global profession: An autoethnography. TESOL Quarterly 46(2): 258-279.

Chang, Heewon, Faith Ngunjiri and Kathy-Ann C. Hernandez. 2016. Collaborative autoethnography. Routledge.

Haase, Saane, Helen Chen, Sheri Sheppard, Anette Kolmos and Niels Mejlgaard. 2013. What does it take to become a good engineer? Identifying cross-national engineering student profiles according to perceived importance of skills. International Journal of Engineering Education 29(3): 698-713.

Hernández, Fernando, Juana Sancho, Amalia Creus and Alejandra Montané. 2010. Becoming university scholars: Inside professional autoethnographies. Journal of Research Practice 6(1): 7.

Herrington, Jan and Ron Oliver. 2000. Educational Technology Research and Development. Educational Technology Research and Development Vol. 48. Springer Science \& Business Media B.V.

Heyden, Bjorn P. von der. 2018. Interviews with professional geologists enhance learning about the applied aspects of economic geology for final-year university students. Journal of Geoscience Education October: 1-14.

Kang, Min Jeong, Ming Hsu, Ian M. Krajbich, George Loewenstein, Samuel M. McClure, Joseph Taoyi Wang and Colin F. Camerer. 2009. The wick in the candle of learning. Psychological Science 20(8): 963-973.

Land, Ray, Jan H. F. Meyer and Michael T. Flanagan. (Eds.). 2016. Threshold concepts in practice. Rotterdam, The Netherlands: Sense Publishers.

Laurillard, Diana, Patricia Charlton, Brock Craft, Dionisios Dimakopoulos, Dejan Ljubojevic, George Magoulas, Elizabeth Masterman, Roser Pujadas, Edgar Whitley and Kim Whittlestone. 2013. A constructionist learning environment for teachers to model learning designs. Journal of Computer Assisted Learning 29(1): 15-30.

Luescher, Thierry M. 2016. Frantz Fanon and the \#MustFall movements in South Africa. International Higher Education 0(85): 22.

MacLure, Maggie. 2013. The wonder of data. Cultural Studies $\leftrightarrow$ Critical Methodologies 13(4): 22832.

Maton, Karl. 2009. Cumulative and segmented learning: Exploring the role of curriculum structures in knowledge-building. British Journal of Sociology of Education 30(1): 43-57.

Maton, Karl. 2013. Making semantic waves: A key to cumulative knowledge-building. Linguistics and Education 24(1): 8-22.

Moje, Elizabeth. 2007. Chapter 1: Developing socially just subject-matter instruction: A review of the literature on disciplinary literacy teaching. Review of Research in Education 31(1): 1-44.

Müller, Marguerite. 2017. Are you happy now? A fictional narrative exploration of educator experiences in higher education during the time of \#FeesMustFall. Education as Change 21(2): $208-236$.

Neve, Hilary, Andy Wearn and Tracey Collett. 2016. What are threshold concepts and how can they inform medical education? Medical Teacher 38(8): 850-853.

Pott, Robert, Karen Wolff and Neill Goosen. 2017. Using an informal competitive practical to stimulate links between the theoretical and practical in fluid mechanics: A case study in nonassessment driven learning approaches. Education for Chemical Engineers 21.

Reed-Danahay, Deborah. 1997. Auto/Ethnography: Rewriting the self and the social. Berg.

Short, Nigel P., Lydia Turner and Alec Grant. (Eds.). 2013. Contemporary British Autoethnography. Sense Publishers.

Taguchi, Hillevi Lenz. 2012. A diffractive and Deleuzian approach to analysing interview data. 
Feminist Theory 13(3): 265-281.

Tronto, Joan C. 1993. Moral boundaries: A political argument for an ethic of care. Routledge.

Tronto, Joan. 2013. Caring democracy : Markets, equality, and justice. New York University Press.

Wanberg, Connie, Leaetta Hough and Zhaoli Song. 2002. Predictive validity of a multidisciplinary model of reemployment success. Journal of Applied Psychology 87(6): 1100-1120.

Warren, John. 2011. Reflexive teaching: Toward critical autoethnographic practices of/in/on pedagogy. Cultural Studies $\leftrightarrow$ Critical Methodologies 11(2): 139-144.

Wolpe, Harold. 1995. The debate on university transformation in South Africa: The case of the University of the Western Cape. Comparative Education 31(2): 275-292.

Zembylas, Michalinos and Vivienne Bozalek. 2017. Re-imagining socially just pedagogies in higher education: The contribution of contemporary theoretical perspectives. Education as Change 21(2): $1-5$.

Zikic, Jelena and Alan M. Saks. 2009. Job search and social cognitive theory: The role of career-relevant activities. Journal of Vocational Behavior 74(1): 117-127. 